\title{
Frost Protection for Georgia Peach Varieties: Current Practices and Information Needs
}

\author{
Skyler Simnitt ${ }^{1,5}$, Tatiana Borisova ${ }^{2,6,9}$, Dario Chavez ${ }^{3,7}$, and \\ Mercy Olmstead ${ }^{4,8}$
}

ADDITIONAL INDEX WORDs. freeze damage, active and passive methods, irrigation, wind machines, producer interview

Summary. The study focuses on frost protection for early-season (early-ripening) peach (Prunus persica) varieties, which are an important crop for producers in the southeastern United States. Using in-depth interviews with four major Georgia peach producers, we explore their frost protection management strategies. This information is the first step in developing a comprehensive research agenda to advise cost-effective frost protection methods for peach cultivation. We found that peach producers are concerned about frost impacts on their crops. Although early-season peach varieties are particularly susceptible to frost impacts, producers still dedicate significant acreage to these varieties, aiming to extend the market window, satisfy sales contracts, and meet obligations for hired labor. However, early-season varieties do not result in high profits, so producers prefer to concentrate on frost protection for mid- and late-season varieties. Producers employ a variety of frost protection methods, including passive methods (such as planting sensitive varieties in areas less susceptible to frost and adjusting pruning/thinning schedules) and active methods (such as frost protection irrigation and wind machines). The choice among active frost protection methods is based on factors such as the planning horizon, initial investment needs, frequency of frost events, and the effectiveness of the frost protection method. Problem areas that producers identified included improving the effectiveness of frost protection methods; reducing initial investments required to install frost protection systems; and employing better spatial targeting and configuration of frost protection strategies (to reduce investment costs while maintaining or improving the effectiveness of frost protection). Although the initial investment costs of enhanced protection systems may limit producers from actually adopting such methods, the operating costs of such systems are relatively low and have a limited effect on the decision to employ frost protection during a particular frost event. However, producers use information about critical temperatures for different bud stages, and hence, improving the quality of information regarding frost susceptibility can help producers make better frost protection decisions (and potentially reduce electricity costs and water use for frost protection).

$\mathrm{C}$ old weather damage causes more crop losses in U.S. agriculture than any other weather event (Snyder et al., 2005). This is especially true in the fruit and vegetable sector where the economic value per acre is particularly high (McCartney and Lefsrud, 2015). For peach and other stone fruit, flower initiation starts in midsummer and continues for several weeks. Enough flower buds are formed each year to secure a good crop in the proceeding year. Peach trees require chill accumulation each year to break dormancy; once trees break dormancy in the spring, budbreak and flower development occurs, and during this period cold weather events can damage blossoms reducing yield (Reighard, 1998). Losses due to cold weather events vary in magnitude and, in some years, an entire crop can be lost (Reiger and Myers, 1990).
Cold weather events are referred to as freezes or frosts, terms which are often used interchangeably by producers and the general public to refer to air temperatures below $32^{\circ} \mathrm{F}$ (Synder et al., 2005). In the literature, freeze and frost definitions vary, with some sources differentiating the events based on air temperature, dew point, wind, and ice crystals formation (NOAA, 2009), whereas others focus on plant conditions. Synder et al. (2005) define frost as an event with air temperatures at or below $32^{\circ} \mathrm{F}$, with a frost event becoming a freeze event when extracellular water in plant tissue freezes. This may or may not cause damage to the plant; however, there is a temperature level referred to as "critical" at which irreversible damage to plant tissues occurs due to intracellular water freezing, causing freeze injuries. These critical freezing bud temperatures can depend on variety, plant stage, or other conditions, leaving uncertainty and subjectivity in producers' frost protection decisions.

Researchers have examined amelioration strategies and made recommendations to producers, focusing on the decision criteria used to choose and apply particular frost protection methods (Francko, 2011; Hellickson, 2006; Williamson, 2010). Passive protection methods are often among producers' most effective and least costly strategies, and they include preventative actions usually implemented long before a freezing event occurs, such as selecting the planting location and an appropriate variety (Morrow and Martsolf, 2004; Perry, 1998; Synder et al., 2005). Active methods are implemented during or shortly before a freeze. A common active frost protection method is overhead sprinkler irrigation, in which the tree is coated with a constant flow of water to form ice around the sensitive plant tissue. This process releases heat as the water freezes (latent heat of fusion of water), thus maintaining the temperature of tissue at, or slightly above freezing as long as the ice remains wet (McCartney and Lefsrud, 2015). Another active method uses wind machines to mix the cold air around the trees with a warmer upper air layer to keep trees from freezing (Crawford and Leonard, 1960; Frazer, 2010; Lehnert, 2013). For active frost protection methods, the decision of when to frost-protect peach trees is dependent on the stage

\begin{tabular}{llll}
\hline $\begin{array}{l}\text { Units } \\
\text { To convert U.S. to SI, } \\
\text { multiply by }\end{array}$ & U.S. unit & SI unit & $\begin{array}{l}\text { To convert SI to U.S., } \\
\text { multiply by }\end{array}$ \\
\hline 0.4047 & acre $(\mathrm{s})$ & $\mathrm{ha}$ & 2.4711 \\
0.3048 & $\mathrm{ft}$ & $\mathrm{m}$ & 3.2808 \\
3.7854 & gal & $\mathrm{L}$ & 0.2642 \\
2.54 & inch $(\mathrm{es})$ & $\mathrm{cm}$ & 0.3937 \\
0.9072 & ton $(\mathrm{s})$ & $\mathrm{Mg}$ & 1.1023 \\
$\left({ }^{\circ} \mathrm{F}-32\right) \div 1.8$ & ${ }^{\circ} \mathrm{F}$ & ${ }^{\circ} \mathrm{C}$ & $\left({ }^{\circ} \mathrm{C} \times 1.8\right)+32$
\end{tabular}


of bud or fruit development and the weather conditions (Longstroth, 2012).

Practical applications of active frost protection methods vary from location to location, across crop types, and type of cold weather event (e.g., advective or radiative freezes) (Longstroth, 2012). While there are various research and outreach publications advising producers on the best methods to choose, few studies examine the rationales and actual choices made by peach producers to frostprotect their crop (Perez, 2004; Zilkah et al., 1996). Past research focused on identifying the optimal frost protection strategy (Synder et al., 2005) and on examining the value and use of weather forecast information in frost protection and other agricultural production decisions (Artikov et al., 2006; Hu et al., 2006; Knocklow et al., 2010; Kusunose and Mahmood, 2016). The need for additional empirical research to examine practices actually used by producers has been identified (Kusunose and Mahmood, 2016).

The purpose of this study is to empirically examine producers' frost protection management as a first step in developing a comprehensive research

\footnotetext{
The authors appreciate the contribution to this research of Georgia's four major peach producers, as well as the feedback for this project provided by Elizabeth Conlan, Carol Fountain, Ariel Singerman, and Erick Smith. Funding for this project is provided by Florida Department of Agriculture and Consumer Services grant "Critical Bud Temperature Determination in Peach and Blueberries to Improve Frost Mitigation Decisions" (00120462 FDACS, PI: Mercy Olmstead).

The authors appreciate the weather data that became available from University of Georgia Weather Network (weather.uga.edu) and suggestions by four anonymous reviewers.

${ }^{1}$ Food and Resource Economics Department, University of Florida, 1103 McCarty Hall B, P.O. Box 110240, Gainesville, FL 32611

${ }^{2}$ Food and Resource Economics Department, University of Florida, 1097 McCarty Hall B, P.O. Box 110240, Gainesville, FL 32611

${ }^{3}$ Department of Horticulture, University of Georgia, Room 105, Stress Physiology Building, 1109 Experiment Street, Griffin, GA 30223

${ }^{4}$ Horticultural Sciences Department, University of Florida, 2135 Fifield Hall, Gainesville, FL 32611

${ }^{5}$ Graduate student

${ }^{6}$ Associate Professor and Extension Specialist (Water Economics)

${ }^{7}$ ASHS Member; Assistant Professor and Extension Specialist (Peach)

${ }^{8}$ ASHS Member; Fruit Production Specialist and Courtesy Professor

${ }^{9}$ Corresponding author. E-mail: tborisova@ufl.edu.

doi: 10.21273/HORTTECH03590-16
}

agenda to advise cost-effective frost protection methods for peach cultivation. Our focus is on frost protection for early-season peach varieties, which are an important crop for producers in the southeastern United States. Producers in southern locations such as Georgia and Florida can produce crops earlier in the season and supply the market before those farther north, thus benefiting from higher sale prices (Morgan and Olmstead, 2013).

Peach production is an economically important agricultural crop in Georgia. The state gained fame for its sweet-tasting peach in the post-Civil War era, when the peach was adopted as Georgia's official fruit. Today, Georgia is ranked third in the nation in terms of peach production (after California and South Carolina), with 10,000 acres dedicated to peach trees, for an estimated used production of 33,700 tons valued at $\$ 35$ million (U.S. Department of Agriculture, 2015). Georgia peach producers have successfully differentiated and marketed their product, with consumers recognizing and seeking Georgia-grown peaches (Plattner et al., 2014; Raper et al., 2009). Even though Georgia's mild southern climate lends itself well to peach production, fruit yield is affected by spring freezes in the state (Haire, 2007; Taylor, 2003).

Given the importance of peach production in Georgia and the risk of frost damage to producers' yields and profits, we examine producers' current approaches to frost protection management. Focusing on Georgia peach production, we use qualitative research methods to enable extension to develop the best management practices for frost protection. Active research is being conducted in many states to improve frost protection methods; this paper is part of the needs assessment to guide this research in selecting the main research directions in response to producers' needs.

Qualitative data analysis methods have been a primary research strategy of anthropologists and ethnographers since the early twentieth century, with the methods gaining traction among other disciplines in the 1960s (Reeves et al., 2008). The grounded theory approach by Glaser and Strauss (1967) demonstrates that coding personal interviews can facilitate a scientifically rigorous analysis of interview data.
Labor and development economists likewise rely on qualitative data to study phenomena inadequately captured in traditional quantitative data sets (Piore, 1969; Twyman et al., 2015). Although qualitative case studies are criticized as myopic by some, they also provide a number of advantages over traditional quantitative research methods by providing a more holistic view of the issues and opinions examined (Noor, 2008).

\section{Methods}

Interviews with four of Georgia's largest peach producers were used to collect data. Georgia peach production is concentrated, with only five producers controlling $95 \%$ of the peach acreage in the state. Although Georgia has only a handful of major producers, these producers apply a diverse range of frost protection methods, thus allowing for an in-depth comparison of the frost protection decision-making processes. The four interviewed producers account for $\approx 75 \%$ of total peach production in the state, with a combined total acreage of $\approx 7000$ acres.

The semistructured interview method was used when broad interview questions are supplemented with clarification questions to examine a specific topic in depth (Wengraf, 2001). Following the existing literature summarizing the determinants of agricultural frost protection decisions (Synder et al., 2005), broad interview questions were selected to examine whether the producers are concerned about frost impact on their farms, which frost protection methods are used, how the methods are selected, and how producers gauge the potential value of better information regarding frost protection methods (i.e., priorities for research in frost protection). Following the methodology outlined in Wengraf (2001), we divided these central questions into a series of broad topics, and identified more specific interview questions to examine producers' behavior (Appendix A). All interview questions used in this study were reviewed by and received formal approval from the University of Georgia Internal Review Board (no. 00002785).

According to Wengraf (2001), one should analyze qualitative data in a manner similar to that in which she or he created the data collection instrument (i.e., interview questionnaire). This means that in successive 
reads of the interview transcript the researcher should move from having specific to more general theory topics and questions in mind. The researcher can employ parsing according to a predetermined rubric, wherein she or he identifies strings of text related to specific theory questions, and applies labels to strings of text of interest to that question. Relevant strings of text can be further identified by specific themes or categories within a theory question (Flick, 2014).

The interviews in this study were transcribed, and the transcripts were reviewed by the research team to identify recurrent themes. We assigned codes to relevant themes for organizational purposes. On additional reviews of the text, themes were further divided into subthemes. For example, we subdivided the theme "passive frost protection strategies" into "pruning" and "site selection." Thereafter, we applied a judicial write-up method (Robson, 1993).

\section{Results}

The interviews were conducted in Oct. 2015. The research team visited four farms, and interviewed six farm owners/managers (at one of the sites, two farm owners and one farm manager were interviewed as a group). All interviewees signed a document of informed consent before being interviewed. In addition, at two of the sites, an extension educator and a former extension educator (now consultant) attended the interviews and asked additional questions or offered additional insights.

The operations range from roughly 3000 bearing and nonbearing acres of peach trees to $\approx 700$ acres. Three of the four farms also devote considerable acreage ( $50 \%$ or more) to other crops [pecan (Carya illinoinensis) or timber]. The operations are situated in the same part of the state, known as Georgia's historic peach country; however, they cover a diverse topography and are affected by microclimates.

All participants had extensive knowledge of peach production. Although one of the producers was relatively new to peach production (i.e., ran operation for about 10 years), the others had grown up on the same farm they owned and managed, with their operations having been in their families for several generations. Of the interviewees, two producers and one farm manager were in the $35-45$ years age range category, one producer was in the 46-54 years age range category, and two producers were more than 65 years old. All participants interviewed had at minimum a bachelor's degree. One of the themes that emerged as the producers spoke of their ties to the industry and experience growing peach was a strong sense of place and connection to the geography of their own operations and surrounding townships.

In addition to fresh fruit sales, all of the interviewed producers maintain retail operations on their farms and have an online presence. The retail operations are part of the tradition and culture, and supply a portion of the producers' profits. Some producers are establishing revenue sources beyond the "traditional farm to supermarket peach production chain." For example, one of the participants suggested that his operation is investing in retail and marketing rather than in cultivating nonpeach crops.

CONCERNS ABOUT FROST IMPACTS. Georgia farmers are highly concerned with frost impact. When we asked participants to rate their concerns about frost damage on a scale of 1 to 5 , with 1 being "least concerned" and 5 being "most concerned," all participants responded with 5 . As frost events are a major threat to yields and profits, it is not surprising that interviewees take several measures to combat frost events. Producers indicated that early-, mid-, and late-season varieties can all be hit by frost; however, generally, earlier varieties are more susceptible. As one producer stated, "over the course of time early varieties ... bloom earlier, [so] they get hit by frost more, [and] that's fairly consistent."

DECISION TO GROW EARLYSEASON PEACH VARIETIES. Early-season varieties are the most susceptible to frost impact, so why do producers grow these varieties? We expected Georgia peach producers to grow early-season varieties because these are more profitable due to the lack of concurrent competition in the national market and higher sale prices. Surprisingly, on three of the four farms, producers indicated that while early-season peach fetch a higher price at market, these varieties are among their least profitable. The producers stated that nearly all production costs relative to peach production are the same per acre regardless of yield per tree (the only exception is piece-rate labor costs). At the same time, earlyseason peach varieties produce far less yield per acre than do mid- and lateseason varieties. Harvest records provided by one of the producers suggest that early-season varieties on average produce $60 \%$ less fruit than later season varieties. As a result, early-season varieties have a significantly higher cost per unit of harvested peaches.

Producers also indicated that the early-season peach varieties are often smaller, making them less marketable as many retailers only accept fruit with a minimum 2.5 inches diameter. Three producers independently suggested that "it's better to have no peaches than small peaches," and they expressed doubt over whether early-season peach varieties are worth producing at all, given their low productivity and risk of smaller fruit.

At the same time, interviewees at three of the four farms indicated that they dedicate relatively large sections of acreage to early-season peach varieties. Two of them explained that they produce earlier ripening varieties as a means of fulfilling contractual obligations with retailers. Producers sell a large proportion of their produce to supermarkets, and to secure agreements with the supermarket chains they supply, the producers commit to providing a product during a number of weeks extending beyond the peak season. Participants indicated that producing early-season varieties enables them to "get to retailers early" and "ease into the market" to establish contracts. This in turn allows them to secure more lucrative long-term agreements that last to the end of the season (i.e., August). Overall, by incorporating early- and late-season varieties, Georgia producers succeed in extending their market windows.

Participants also suggested that using storage space was an important factor motivating them to extend the season by growing early-season peach varieties. A participant shared that by spreading out the harvest over several months he is able to produce a high seasonal volume without exceeding his bin capacity. Following this same line of reasoning, another participant explained that by spreading out the harvest over several months between early-, mid-, and late-season varieties, 
he is better able to keep his labor crew occupied. This grower primarily uses guest workers hired under the $\mathrm{H}-2 \mathrm{~A}$ visa program, a program, which allows U.S. farmers to bring in foreign workers for temporary or seasonal work. According to program rules the hiring party must provide wages for $75 \%$ of the contracted season regardless of production. In the short run, this leaves the grower's labor supply highly inelastic, or as he stated, "my labor [contract] demands work every day, and the grocery stores want a continuous supply. It causes big problems when I don't have fruit to pick every day."

Overall, producers believed that despite the early-season peach varieties being among the least profitable to produce, they are an important part of their marketing strategy. Interviewees on all four farms confirmed that because early-season varieties are generally more susceptible to early frost events due to their blooming schedule, they are equally concerned with preserving yields of the more profitable mid- and late-season varieties during a freeze event. Thus, our discussion of frost protection methods encompassed the protection of all varieties rather than focusing more on early-season varieties.

Frost protection STRATEgies USED. Producers use a variety of active and passive frost protection strategies. As one participant stated, "frost protection starts from before you plant the tree" and another similarly indicated, "you can technically call everything we do frost protection from site selection to herbicide strips."

Although all the producers we interviewed operate within a relatively small geographical area of central Georgia, there is considerable variation in the terrain covered by their orchards, particularly in terms of elevation. Their reported management decisions, including the use of frost protection and the varieties of peaches they grow, are undoubtedly influenced by both terrain and weather patterns, although we are unable to determine the extent of that influence given the nature of the data collected and the scope of our present analysis.

Passive methods. When asked what frost protection methods they used, all mentioned pruning and tree placement. One of the senior participants mentioned multiple times during the interview that "producers have a lot of experience and accumulated knowledge," thus, they know before planting a particular variety how frost tender (i.e., susceptible) it is. Furthermore, they carefully prepare the land before planting, removing wind barriers, brush, and other obstructions that might prevent cold air drainage. One of the junior associates indicated that producers must consider elevation when deciding where to plant a tree because a rise or drop in elevation of only a few feet can result in temperature differences of several degrees.

All participants mentioned pruning as one of the main means of frost protection. Pruning is an integral part of peach cultivation in the weeks preceding bloom. It reduces the overall number of flower buds on the tree, ultimately increasing fruit size and quality. When asked about the percentage of buds that can be lost or removed from a tree and still produce a full crop, participants' responses varied from $60 \%$ to $90 \%$. Pruning is conducted in stages allowing producers to protect against unexpected frost events. Producers will intentionally limit pruning (underprune) particular trees during early stages of bud development to leave excess blossoms on the trees or to delay bud development (rather than chemical treatments for bloom delay as in other parts of country). As one of the producers explained, it is an insurance policy to increase the chance that some buds will survive subsequent frosts. However, underpruning can result in smaller fruit size if fruit density is not reduced before the optimal thinning time (30-40 d after bloom). In turn, pruning and thinning the same tree several times leads to higher production costs. As one participant explained, "there's a point where you start sacrificing size" by leaving excess flower buds on the tree.

ACtive Methods. Producers rely on a diverse set of active frost protection methods, reflecting local microclimate, terrains, perception of the frequency of frost events, and the willingness of the owners/operators to experiment with new frost protection methods. Producers mentioned the use of irrigation and portable wind machines, as well as low capital approaches. As one study participant stated,

We tried everything. We tried burning debris in the field, we tried helicopters flying over, and we tried clearing the land around so you've got air movement through ... you make sure that the ground moisture is there when you have irrigation.

Irrigation for frost protection relies on a preexisting system of supplemental irrigation, drip- or microsprinklers. Producers typically irrigate the evening preceding a forecasted freeze. Increased soil water content in the orchard may increase surrounding air temperature; furthermore, wet ground absorbs and transmits radiative heat more readily than does dry ground. Participants indicated that this method of protection frequently provides lackluster results depending on the severity of the minimum temperature and the critical temperature at which damage occurs to the buds. As one of study participants explained regarding irrigation,

A lot of our irrigation is ... built for
supplemental irrigation of the crop.
It's not built for enough water to
adequately frost protect ... [W] hen
a frost is coming, we turn it on
anyway to try and wet whatever
ground we can wet and soak up as
much heat as we can, so it may or
may not help.

One of the four operations we visited uses a sprinkler irrigation system especially designed to deliver volumes of water sufficient for frost protection. After hearing that one of the operations uses portable wind machines, participants from two of the other operations expressed interest in potentially installing wind machines.

General themes that emerged in the discussion of the choice among frost protection methods were initial investment cost, the perceived effectiveness and benefits associated with the method, the frequency of frost events, and the planning horizon.

The Choice among active FROST PROTECTION METHODS: PLANNING HORIZON. The theme of the planning horizon appeared in the discussion of the difference between portable frost fans and permanent wind towers commonly used on apple farms and other deciduous orchards. One producer suggested that due to the relatively short productive 
life of a peach orchard ( $12-15$ years) compared with other fruiting trees, it is not cost-effective to invest in permanent wind machine structures:

I've only got six or seven years of crop to protect. In the back end of that is usually a dwindling stand of trees, so I've really only got 3, 4,5 years of full crop to potentially protect, so it's really hard for me to want to go through the expense of erecting a structure like that to protect 10 acres [per wind machine structure].

At the same time, wind machines are a relatively new method of frost protection in the southeastern United States, and hence, producers are still figuring out the best practices for their use. For example, producers may need to account for the fact that when they renovate an orchard, they usually replant in peach trees, meaning that the wind machines can still be used to protect the new orchard, thus expanding their useful lifespan.

The Choice among active FROST PROTECTION METHODS: COST. Investment costs are a big factor in choosing the frost protection method, often creating a barrier for using any active frost protection. For example, to use irrigation for frost protection, producers need the ability to apply a significant volume of water (up to $0.9 \mathrm{inch} / \mathrm{h}$ ) to the plant continuously during the freeze event. However, basic irrigation systems available to most producers do not allow flow rates sufficient for frost protection. The costs to convert a basic irrigation system for frost protection use are substantial. As one producer explained,

It's a whole bunch of water that you don't ever need to irrigate the crop ... It's a huge investment in the well [and] the plumbing to be able to deliver that much water at one time. We have it in places but not farm-wide.

Similarly, with regard to wind machines, all the producers indicated that they are expensive to purchase given the expected coverage. One producer explained that "one wind machine does 5 acres. A wind machine I think is around $\$ 25,000$, so dual machines will get you about 12 acres. Yes, it gets very expensive." Although the producers we spoke with largely focused on portable wind machines, permanent wind machines can be even more expensive $(\$ 30,000$ to $\$ 40,000$, with protection for 10-12 acres each). Producers in the study area were cultivating between 700 and 1400 acres, and for them, the investment cost was a considerable concern. None of them mentioned lease purchase options that may be available and allow spreading the payment for the machines into several years, bringing annual costs down.

Given the high investment costs, producers are seeking strategies to target frost protection to those areas and varieties on their farms that would result in the greatest benefits (i.e., for saving mid- and late-season varieties that produce higher yields and per acre profits). As one grower stated,

If I've got one wind machine, where do I put it? Where can I save the most money with the machine? It's not with May peaches or June peaches. It's where you can make the most peaches with the market somewhat high. Not in August when peaches are cheap, not May when you can't make any peaches. Right around the week before "FirePrince" where I can make 3 or 4 bushels and guarantee them.

The Choice among active FROST PROTECTION METHODS: BENEFITS. A prevalent theme was the general lack of confidence the producers have in the available protection methods. One owner made a statement, which characterizes a sentiment held by the others, which is, "I haven't enough confidence that there is a foolproof frost protection method out there." Still another grower stated that "at one time it [frost protection] was something I very aggressively looked at and wanted to do; the last few years, I've said I just can't beat it."

Producers undoubtedly would like a frost protection system that protects under all conditions; however, no such system yet exists. Irrigation allows $2-3{ }^{\circ} \mathrm{F}$ of protection, and frost fans allow upwards of $5-6^{\circ} \mathrm{F}$ of protection (Powell and Himelrick, 2000). For example, the producer using wind machines believes they are effective: "Wind machines work, I've run them for two or three years, and every year I can see exactly where it protected the crop and where it stopped protecting it." Despite his positive experience, he realizes that the wind machines have limitations, especially on particularly cold days. As he stated, “a wind machine isn't going to save that ... I can add a degree or two, but it's not like it's going to make a difference."

Although producers can determine the investment and operating costs of various protection methods, the effectiveness and benefits of these methods are far more difficult to quantify, since it is contingent on freeze conditions, inversion height, and other event specific factors. This leaves room for subjective judgment because each grower must assess the degree of protection according to his own perception. It is unsurprising that producers were unable to quantify the exact coverage or percentage of their annual yield preserved by the frost protection methods they use. For the methods that provide partial coverage (such as wind machines), spatial targeting can reduce the investment costs; however, partial yields may be less desirable than a total crop failure, especially when crop insurance is involved. As one grower stated,

Say, you have a 40-acre field and there's 10 acres on this slope gets cold, and you want to put fans there. So you put fans there and a week later it really worked, but on the top side it got so cold everything is dead. Did you really want this 10 acres in the corner or would you just rather that they be gone as well?

Operating cost of active FROST PROTECTION SYSTEMS. Producers consider bud development stages and related critical temperatures in their frost protection decisions, thus minimizing the use of active frost protection when it is not needed. Those interviewed were able to quickly recall at what stages of bud development they employ irrigation given the severity of a freeze. For example, one of the producers indicated that at "green calyx" and "first pink" he is less worried about frost damage and would only apply it given the temperature drops to near or below $18{ }^{\circ} \mathrm{F}$. On the other hand, when his trees arrive at the "petal fall" and "full bloom" development stages he is much more likely to apply frost protection at temperatures near freezing $\left(33-32^{\circ} \mathrm{F}\right)$.

Other producers indicated that for nights when the temperature is expected to drop below the critical level, they switch on active frost protection 


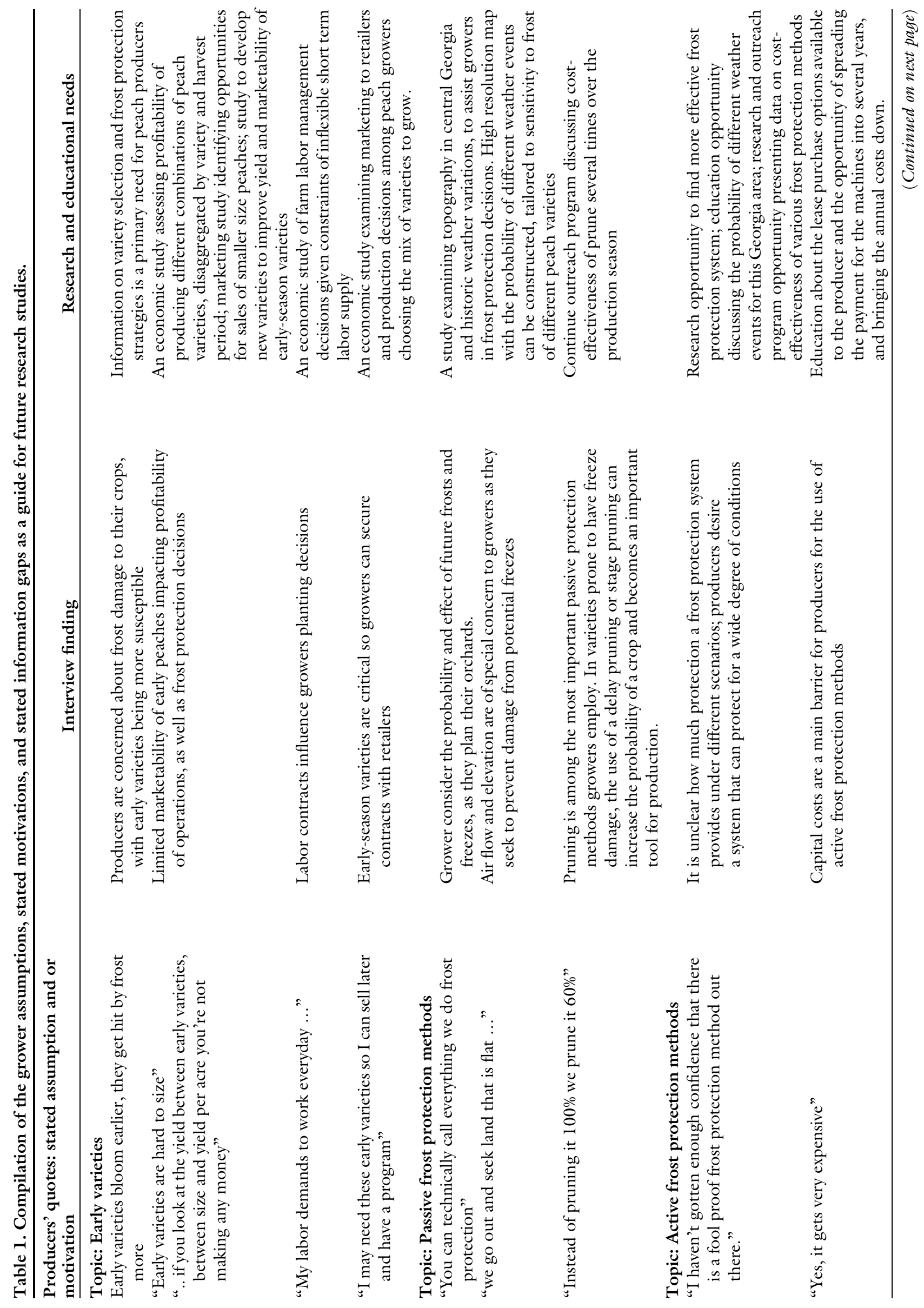

Hortlechnology · June 2017 27(3) 


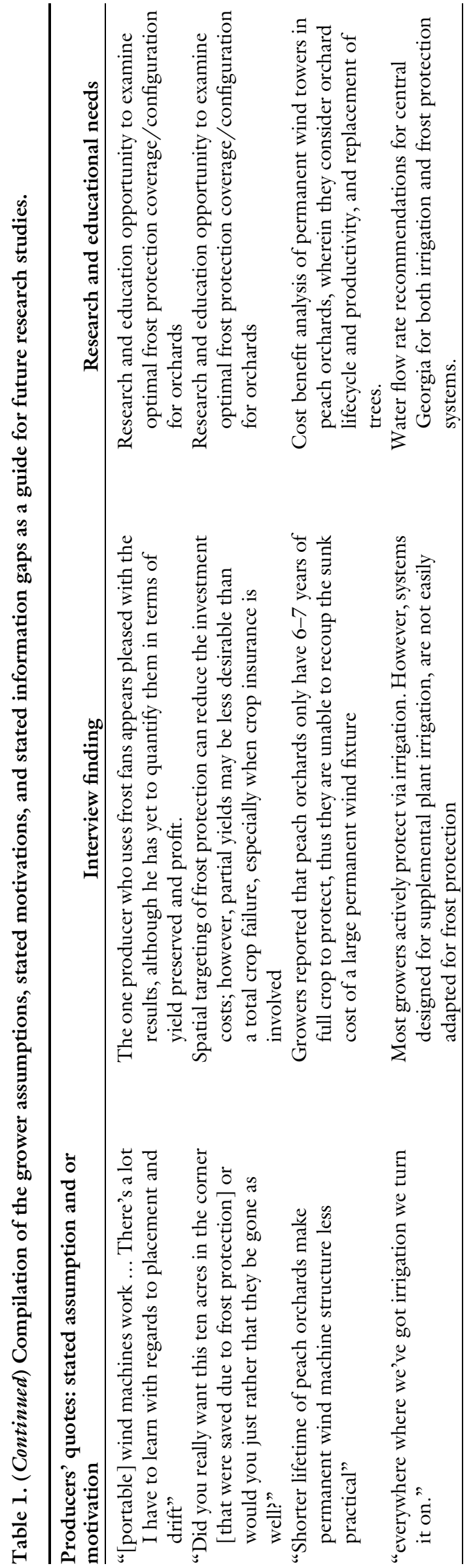

at $34^{\circ} \mathrm{F}$. Likewise, their responses for what temperature they consider safe to discontinue their protection method varied from 35 to $38^{\circ} \mathrm{F}$.

The producers also consider frequency and duration of events that require frost protection, stating that "here we're not talking about winter enduring like up north; we're talking about literally in most years two or three nights." For such relatively low frequency and short duration of frost protection events, the operation costs of frost protection irrigation and wind machines seem to be too low to sway producers' opinion not to apply frost protection. As one grower using frost protection irrigation stated, "a gallon or two of gas in a morning, it's no big deal. It's not expensive to run it [frost protection irrigation]." $\mathrm{He}$ further added, "personally, I couldn't live with myself if I didn't spend \$2000 trying to save the crop I spent all year trying to grow ... It's not only an economic thing, I'm going to try and do everything I can to save it," showing that producers have a high commitment to protecting their crops.

Our analysis of weather data for the Georgia peach-producing region shows that Georgia producers experience about one cold weather event that requires active protection for one or two nights (Appendix B). The frost protection irrigation cost ranges from $\$ 1.66$ to $\$ 1.72$ per hour per acre for underplant or overhead sprinkler irrigation (Synder et al., 2005). The fuel costs for diesel wind machines are estimated at $\$ 1.45 /$ acre using $6 \mathrm{gal} / \mathrm{h}$ of diesel (Blank and Venner 1995), based on a diesel price of $\$ 2.421 /$ gal (EIA, 2016) and each wind machine serving 10 acres. Assuming one event per year for $12 \mathrm{~h}$ every night (from 10:00 PM to 10:00 AM) for two consecutive nights, frost protection costs are less than $\$ 50 /$ acre per year. These costs account for only a small proportion of the total peach production costs $(\$ 3802.75 /$ acre $)$ or the potential sales $(\$ 5590.00 /$ acre $)$ (Fonsah et al., 2008). Note that for low capital technologies (such as the use of helicopters), operating cost are significantly higher and they can still be prohibitive.

Priorities for Developing FUTURE FROST PROTECTION STRATEgIES. The producers mentioned a variety of limitations impacting their frost protection decisions 
which might direct the priorities of future research and extension. The main themes that emerged in our discussion with producers are a lack of confidence in, and a perceived lack of, effectiveness of current frost protection methods; the need for improved spatial targeting of frost protection; and improved configuration of frost protection systems to improve effectiveness and minimize investment costs.

Throughout our discussions, it became clear that the producers were unsure as to the effectiveness of the frost protection methods currently available. This theme was perhaps best captured when we asked the producers to describe their "ideal" frost protection system. Two of the producers responded, to the effect that as far as they knew there is no "fool-safe" protection method. The producers were dissatisfied that the protection methods available to them were only effective within a limited range of temperatures. As such, one grower suggested that his ideal system would include a way to protect trees at even colder temperatures. $\mathrm{He}$ said, "Have to be able to inject heat into the environment if you're going to be able to protect down to $20^{\circ} \mathrm{F}$." $\mathrm{He}$ indicated that he would consider using his frost fans along with a heat source to increase their effectiveness. While there are studies on the combined benefits of wind machines, this method may yet prove fertile ground for future development, particularly in the context of peach orchards (Evans, 2008).

Given that frost protection can require significant investments, producers see improving spatial configuration and spatial targeting as a priority for future frost protection research. As one grower put it: "I don't tend to lose the whole orchard; typically, I lose pieces of it ... and that's where I want to protect." From this perspective, the mobility of portable wind machines was mentioned as an advantage by protecting the most cold-sensitive sections of the orchard, changing locations with the change in blooming stages for different varieties, and minimizing expenses.

Although producers understand that there is no frost protection system that is guaranteed to work $100 \%$ of the time we identified some variability in their understanding of the effectiveness of different frost protection methods, and made recommendations. Although there exists an abundant literature on frost protection in fruit orchards we noticed some disconnect between producers' experiential understanding and the recommendations made in this literature. For this reason, we recommend targeting producers with an education program, bringing them up-to-date on the extant research on frost protection so they more fully understand the advantages and disadvantages of different freeze protection methods and can better determine the costs and benefits of adopting new systems. Additionally, we recommend new collaborative research initiatives between the University of Georgia and local producers, so that horticultural scientists might make recommendations more specific to local weather patterns, topography, and peach varieties.

We asked participants where they obtain their weather information. All participants indicated that they use the Georgia Automated Environmental Monitoring Network [GAEMN (University of Georgia 2015)] for historical data. Three of the four producers indicated that they consult the GAEMN daily. With regard to forecast data, a theme emerged among participants, with producers checking all available websites and weather data sources. While three of the participants indicated that they have thermometers strategically placed in their orchards to help them gauge frost protection decisions, only one of the producers had a private weather station installed on his operation. Two of the participants indicated that they thought derived benefits from weather stations did not justify the investment cost. These findings suggest that in cases where frost protection is targeted at specific sections on the farm (spatial targeting), more precise and spatially specific weather information will add extra value.

Georgia's main peach producers do not use overhead irrigation protection; rather, irrigation protection via wetting the ground around the plants is among their preferred methods of protection. Our findings suggest that the cost of installing an irrigation system capable of frost protecting can be an impediment to producers, so a more cost-effective means of applying water via improved sprinklers may be an area worth researching. One producer using frost protection irrigation was interested in research on improved sprinkler systems. He explained that while he currently uses microjet sprinklers rather than overhead sprinklers because he sees them as far more efficient than the latter, he would be interested in research on alternate models and delivery methods.

\section{Conclusions}

For cultural and historic reasons, the Georgia peach industry is an important part of the state's economy. Our research examines Georgia peach producers' views on frost damage and current methods of protection. Our central research question is about how Georgia peach producers consider and implement frost protection.

We interviewed owners and operators at four operations that account for $75 \%$ of the Georgia peach industry (Table 1). We found producers are concerned with frost protection. Their comments confirm the literature suggesting that frost damage is a leading cause of loss in agriculture. Our findings indicate that Georgia peach producers use a variety of frost protection methods. Among the most prevalent of these are passive methods (tree placement, site selection, and pruning) and active methods (irrigation).

We found that Georgia producers apply under-the-tree irrigation for frost protection via microsprinklers not unlike peach producers in other parts of the country (Evans, 1999). Less common, however, among Georgia producers is the use of frost fans. Although early-season peach varieties are more susceptible to frost, peach producers indicated more concern in frost impacts on their mid- and late-season varieties. It became clear through our discussion with the producers that early-season varieties are only marginally profitable and not worth protection investment, whereas mid- and late-season varieties provide producers the bulk of their profit. In general, the Georgia peach producers we interviewed demonstrate a lack of confidence in current protection methods, citing lack of success and inconsistent results as the main reasons for their reticence to adopt new strategies. The producers confirmed that early-season peach varieties are at greater risk for frost damage. However, contrary to our expectations, they are generally less concerned with reductions in the 
Table 2. Summary statistics for air temperature records available for Ft. Valley Weather Station (Georgia) in 1994-2015.

\begin{tabular}{lccccc}
\hline & & Mean & Median & Minimum & Maximum \\
\cline { 3 - 6 } Month & Observations (no.) & & & $\left({ }^{\circ} \mathbf{F}\right)^{\mathbf{z}}$ & \\
\hline February & 53,496 & 49.07 & 48.70 & 8.44 & 78.75 \\
March & 59,136 & 56.43 & 56.82 & 16.74 & 88.02 \\
April & 59,040 & 63.51 & 63.61 & 28.82 & 90.01 \\
May & 61,008 & 71.51 & 70.86 & 41.94 & 95.94 \\
\hline
\end{tabular}

The air temperature measurements were taken every hour in the period from 1 Feb. 1994 to 26 Mar. 1996. For the period from 27 Mar. 1994 to May 2015, the measurements were taken every $15 \mathrm{~min}$.

${ }^{\mathrm{z}}\left({ }^{\circ} \mathrm{F}-32\right) \div 1.8={ }^{\circ} \mathrm{C}$.

early-season harvest than with midand late-season varieties. It is clear that mid- and late-season peach varieties have a higher marginal benefit to producers than early-season varieties due to the former having much higher yields of marketable fruit.

In our discussion with the producers regarding frost protection irrigation, it became apparent that some may misunderstand recommended water flow rates and assume they need to deliver larger volumes of water to protect their trees than suggested in the literature. Thus there may be an opportunity for education specialists to update producers' knowledge on this subject.

The majority of the producers interviewed demonstrated a reluctance to make large investments on systems that may not successfully protect their crop $100 \%$ of the time. This is understandable given that potentially damaging freeze events occur only a few hours each season; thus across these relatively infrequent yet damaging occurrences, it is important for producers to recoup their investment cost to make peach production economically viable.

While the dominant theme of profit maximization emerged in conjunction with themes such as frost damage, protection costs, and consistent markets, our findings suggest that the producers' frost protection strategies may not be motivated by economic considerations alone. As one of the respondents stated, "Personally, I couldn't live with myself if I didn't spend $\$ 2000$ trying to save the crop I spent all year trying to grow." While this may still reflect the fact that the producer is weighing potential sales revenues vs. frost protection costs, it also hints at noneconomic considerations of producer committed to saving the crop.

Similarly, the theme of a sense of pride in the industry and their business, family legacies, and connectedness to the land emerged throughout our discussions with the producers. These sentiments likely factor into producers' operating decisions, and additional research is needed to explore how they do so.

\section{Literature cited}

Artikov, I., S.J. Hoffman, G.D. Lynne, L.M. Pytlik Zillig, Q. Hu, A.J. Tompkins, K.G. Hubbard, M.J. Hayes, and W. Waltman. 2006. Understanding the influence of climate forecasts on farmer decisions as planned behavior. J. Appl. Meteorol. Climatol. 45(9):1202-1214.

Blank, S.C. and R. Venner. 1995. Evaluating the cost-effectiveness of risk-reducing inputs: Wind machines for citrus. HortTechnology 5:165-170.

Crawford, T.V. and A.S. Leonard. 1960. Wind machine-orchard heater system for frost protection in deciduous orchards. Calif. Agr. 14(8):10-13.

Energy Information Administration. 2016. U.S. on-highway diesel fuel prices. 22 Dec. 2016. <http://www.eia.gov/oog/info/ wohdp/diesel.asp $>$.

Evans, R.G. 1999. Frost protection in orchards and vineyards. Washington State Univ. Coop. Ext. Pullman.

Evans, R.G. 2008. The ABCs of frost management. 22 Dec. 2016. <https://www.ars. usda.gov/SP2UserFiles/person/21563/ Frost $\% 20$ Protection $\% 20$ in $\% 20$ Orchards $\%$ 20and\%20Vineyards-2008.pdf>.

Flick, U. 2014. The sage handbook of qualitative data analysis. Sage, Los Angeles, CA.

Fonsah, E.G., K.C. Taylor, and F. Funderburk. 2008. Middle Georgia peach budget. 22 Dec. 2016. <http://www.caes.uga.edu/ content/dam/caes-website/departments/ agricultural-and-applied-economics / documents/extension/budgets/nonbeef/2008tablesMiddleGaPeachBudget. pdf>.
Francko, D.A. 2011. A tropical spray to enhance plant resistance to cold injury and mortality. HortTechnology 21:109-118.

Frazer, H. 2010. Wind machines for minimizing cold injury to horticultural crops. Fact Sheet Agdex no.748/28. 22 Dec. 2016. <http://www.omafra. gov.on.ca/english/engineer/facts/10045.htm>.

Glaser, B. and A. Strauss. 1967. The discovery of grounded theory: Strategies for qualitative research. Aldine, Chicago, IL.

Haire, B. 2007. Harvest starts on sweeter, pricier Georgia peaches. 22 Dec. 2016. <http://apps.caes.uga.edu/gafaces/index. cfm?public=viewStory\&pk_id=2891 $>$.

Hellickson, M.L. 2006. Environmentally safe orchard heating for frost and freeze protection. 22 Dec. 2016 . <http://www. propanecouncil.org/uploadedFiles/ REP_l1116\%20Environmentally\% 20Safe $\% 20$ Orchard $\% 20$ Heating.pdf>.

Hu, Q., L.M. Pytlik Zillig, G. Lynne, A. Tomkins, W. Waltman, M. Hayes, K. Hubbard, I. Artikov, S. Hoffman, and D. Wilhite. 2006. Understanding farmers' forecast use from their beliefs, values, social norms, and perceived obstacles. J. Appl. Meteorol. Climatol. 45(9):11901201.

Knocklow, K.E., R.A. McPherson, and D.S. Sutter. 2010. On the economic nature of crop production decisions using the Oklahoma Mesonet. Weather Clim. Soc. 2(3):224-236.

Kusunose, Y. and R. Mahmood. 2016. Imperfect forecasts and decision making in agriculture. Agr. Syst. 146(1):103110.

Lehnert, R. 2013. Wind machines: Producers need stable production and can't afford freeze-outs that disrupt markets as well as their pocketbooks. 22 Dec. 2016. <http://www.goodfruit.com/windmachines $/>$.

Longstroth, M. 2012. Freeze damage depends on tree fruit stage of development. 22 Dec. 2016. <http://msue. anr.msu.edu/news/freeze_damage_ depends_on_tree_fruit_stage_of_ development $>$.

McCartney, L. and M. Lefsrud. 2015. Portable frost-protection misting system: Trial on tomato and sweet orange crops. HortTechnology 25:313-321.

Morgan, K.L. and M.A. Olmstead. 2013. A diversification strategy for perennial horticulture in Florida. HortTechnology 23:482-489.

Morrow, T.C. and J.D. Martsolf. 2004. Mitigating cold damage in horticultural 
crops. Crop Environ. Bioinformatics $\mathrm{l}(4): 272-296$.

National Oceanic and Atmospheric Administration (NOAA). 2009. National Weather Service: Glossary. 22 Dec. 2016. <http://wl.weather.gov/glossary/ index.php?letter $=\mathrm{f}>$.

Noor, K.B.M. 2008. Case study: A strategic research methodology. Amer. J. Appl. Sci. 5(11):1602-1604.

Perez, S. 2004. Yield stability of peach germplasm differing in dormancy and blooming season in the Mexican subtropics. Sci. Hort. 100(1-4):15-21.

Perry, K.B. 1998. Basics of frost and freeze protection for horticultural crops. HortTechnology 8:10-15.

Piore, M.J. 1969. Impact of the labor market upon the design and selection of production techniques within the manufacturing plant. Qrtly J. Econ. 82 (4):602-620

Plattner, K.P., A. Perez, and S. Thornsbury. 2014. Evolving U.S. fruit markets and seasonal grower price patterns. $22 \mathrm{Dec}$. 2016. <https://www.ers.usda.gov/ webdocs / publications / fts3570 / 49158_fts-357-01.pdf>.
Powell, A.A. and D.G. Himelrick. 2000 Methods of freeze protection for fruit crops. Alabama Coop. Ext. System Publ. ANR-1057B. I Jan. 2017. <http:// www.aces.edu/pubs/docs/A/ANR1057-B/ANR-1057-B.pdf>.

Raper, K., S. Thornsbury, and C. Aquilar. 2009. Regional wholesale price relationships in the presence of counter-seasonal imports. J. Agr. Appl. Econ. 41(1):271290.

Reeves, S., A. Kuper, and B.D. Hodges. 2008. Qualitative research methodologies: Ethnography. BMJ 337(7668):10201026.

Reiger, M. and S.C. Myers. 1990. Overtree microsprinkler irrigation for spring freeze protection of peaches. HortScience $25: 632-635$

Reighard, G.L. 1998. Manipulation of peach phenology, growth, and fruit maturity using interstems. Acta Hort. (465):567-572.

Robson, C. 1993. Real-world research. 2nd ed. Blackwell, Malden, MA.

Snyder, R.L., J.P. de Melo-Abreu, and S. Matulich. 2005. Frost protection: Fundamentals practice and economics. FAO, Rome, Italy.
Taylor, K.C. 2003. Peaches. 22 Dec. 2016. <http://www.georgiaencyclopedia.org/ articles/business-economy/peaches $>$.

Twyman, J., P. Useche, and C.D. Deere. 2015. Gendered perceptions of land ownership and agricultural decisionmaking in Ecuador. Land Econ. 91 (3):479-500

University of Georgia. 2015. Georgia Automated Environmental Monitoring Network. 22 Dec. 2016. <http://www. georgiaweather.net/>

U.S. Department of Agriculture. 2015. State agricultural overview (Georgia). 22 Dec. 2016. <https://www.nass.usda. gov/Quick_Stats/Ag_Overview/ stateOverview.php? state $=$ GEORGIA $>$.

Wengraf, T. 2001. Qualitative research interviewing: Biographic narrative and semi-structured methods. Sage Publ., Thousand Oaks, CA

Williamson, J.G. 2010. Best management practices for temperate and tropical/ subtropical fruit crops in Florida: Current practices and future challenges. HortTechnology 20:111-119.

Zilkah, S., Z. Weismann, I. Klein, and I. David. 1996. Foliar applied urea improves freezing protection to avocado and peach. Sci. Hort. 66(1-2):85-92. 


\section{Appendix A}

\section{Questions to guide}

semistructured interviews with the Georgia peach producers

1. Demographic questions (age and level of education)

2. How many years have you worked in the peach industry? For how many of these years have you managed the day-to-day operations or this farm?

3 . What are the bearing and nonbearing peach acreage on your $\operatorname{farm}(\mathrm{s})$ ?

4. Which of the varieties of early-blooming peaches (i.e., that bud between early February and mid-March) do you grow? How many acres of each?

5 . Do you water your peach trees via an irrigation system? What type of system do you use?

6. On a scale of 1 to 5 how concerned are you about frost damage? (With one being not all concerned and 5 extremely concerned).

7. (If answered 4 or 5 to the previous question) What concerns you about frost damage?

8. Do you recall any particular season where you experienced substantial yield reduction due to frost damage?

9. (If answered yes to the previous question) Can you tell us about it? About how much of loss did you sustain?

10. How much bud loss can occur before you noticed a reduction in final yield?

11. When it comes to making decisions about your trees, where do you get your weather information from? (Read the list)

a. On-farm weather system/thermometers

b. Georgia Automated Environmental Monitoring Network

c. National Oceanic and Atmospheric

Administration

d. The Weather Channel

e. Weather Underground

f. Accu Weather

g. Other (please, specify)
12. Do you use some kind of frost protection? (if answered yes)

a. What kind?

b. When did you begin using it?

c. How consistently do you use it? (e.g., twice a season)

d. How many bearing acres do you apply it to at a time?

e. Do you only protect the early-ripening varieties discussed previously?

f. How do you decide to apply it/turn it on?

g. Do you consider wet bulb or dry bulb temperature?

$\mathrm{h}$. What is the maximum wind speed at which you would still use your protection?

i. For the various bud stages, for nights where the temperature is predicted to drop below freezing $\left(32^{\circ} \mathrm{F}\right)$, please identify the air temperature $\left({ }^{\circ} \mathrm{F}\right)$ at which you turn on your irrigation system for frost protection.

j. How would an ideas frost protection system look like?

\section{Appendix B}

Analysis of weather records for Georgia peach producing area

Air temperature and wind speed measurements were analyzed for the Fort Valley weather station (University of Georgia, 2015), which is located in the heart of Georgia's peach producing area. February to May period was selected as the period when peaches typically go out of dormancy and hence, can be affected by cold weather events. Air temperature, wind speed, and maximum wind speed data were available for 22 years (1994-2015). The measurements were available for 15-min interval, except for the measurements conducted from l Feb. 1994 to 26 Mar. 1996, which were reported hourly. Based on Longstroth
(2012), bud and flower kill can be observed at various levels of critical air temperatures depending on the bud stages, ranging from $28^{\circ} \mathrm{F}$ (for postbloom) to $25^{\circ} \mathrm{F}$ (for first pink) and to $18^{\circ} \mathrm{F}$ (for swollen buds).

As shown in Table 2, cold weather events that can cause plant damage occur in February to March, when minimum temperature can drop below the critical for all or some bud stages. In February, it is very likely that the temperature will reach $28{ }^{\circ} \mathrm{F}$ or drop below [ $81.8 \%$ probability; event(s) observed in 18 out of 22 years of observation]. February temperature is likely to drop below $25^{\circ} \mathrm{F}$ [ $68.2 \%$ probability; event(s) observed in 15 out of 22 years of observation]. However, the likelihood of temperature dropping below the critical for swollen bud, or $18^{\circ} \mathrm{F}$, is low [9.1\% probability, event(s) observed in 2 out of 22 years]. March is generally warmer, and the events with temperature at or below $28{ }^{\circ} \mathrm{F}$ are relatively unlikely ( 7 out of 22 years of observation, or $31.8 \%$ estimated probability of such an event).

We define cold weather events that can cause frost damage as periods when the air temperature reach or drop below the critical for first pink (i.e., $25^{\circ} \mathrm{F}$ ) in February, and periods with temperature is at or below the critical temperature for the most frost-tender stage-postbloom (i.e., $28{ }^{\circ} \mathrm{F}$ ) in March. For the 22 years of observation, we found 27 such events (1.2 cold weather events per season on average). Further, 10 events were excluded from the analysis, since the maximum wind speed during such events exceeded $10 \mathrm{mph}$, reducing frost protection effectiveness. Hence, it is estimated that on average, there are 0.77 cold weather events per season for which freeze damage can be avoided using freeze protection. On average, each event is estimated to last 1.2 nights, with temperature staying below the critical values for $2.44 \mathrm{~h}$ per night. Note, in the nights with cold weather expected, producers relying on frost protection irrigation would turn their irrigation systems on when temperature drops to $32-34^{\circ} \mathrm{F}$, and turn it off at $32-36^{\circ} \mathrm{F}$, extending the number of hours over which the frost protection is used. 